\section{A SOCIOECONOMIC PROFILE OF THE PORTERS \\ IN THE CENTRAL MID-HILLS OF NEPAL ${ }^{1}$}

Kinan Dutta Upadhyay

\section{Introduction}

No reliable estimates of unemployment and underemployment exist in Nepal: Lack of proper data as well as definitional and conceptional problems have contributed to this situation. One set of data that does exist, a survey carried out by the National Planning Commission in 1977, showed that the rate of unemployment is highest in the hills. At this time, 65 percent of the economically active population of the hills was underemployed (NPC 1978:57). The proportion of underemployed individuals per household is even greater than that of unemployed. For Nepal as a whole, the proportion of unemployed to the total labor force in rural areas stood at 5.52 percent in 1977 . Breaking this rate down by gender, $5.47 \%$ of the men and $5.68 \%$ of the women were unemployed (Jain 1980:3).

Small subsistence farmers predominate in the Hills of Nepal. More than 60 percent of the hill households own less than one hectare of land, and the average size of such holdings is less than 0.5 ha. While the hills and mountains support 65 percent of the total population of Nepal, they consist only 43 percent of the cultivated land. This comes of an average of $0.12 \mathrm{ha}$. per person (CBS 1987:viiix). Increasing crowding of the farmers and declining shares in the total land clearly indicates that the size of the holdings of the lower 50 percent of the households has decreased over the last three decades. The evidence shows that the population is also increasing. The average size of households in the hill districts of Ramechhap and Sindhuli is 5.4 and 6.1 persons respectively (CBS 1984).

Transportation and communication difficulties in the hills have largely been responsible for poor socioeconomic integration of the hill households, resulting in semi-isolated regional pockets. One of the basic characteristics of the employment structure in Nepal. particularly in the hills, is the nearly total lack of sectorial mobility. Land available for agriculture is severely limited by topography, and its productivity has been deteriorating rapidly because of improper landuse practices caused by the mounting population pressure.

\section{8}

Occasional Papers in Sociology and Anthropology, Volume 2 (1990)
Due to such of this difficult socioeconomic milieu, a majority of hill dwellers are always in search of alternatives in addition to agriculture for sources of income. Since other sources of income are scarce, many people have no other choice than porterage, an extremely strenuous form of work.

One contributing factor to the growth of the numbers of people involved in porterage is the Nepal Food Corporation. The Nepal Food Corporation brings rice into the headquarters on the basis of People's participation. For instance, the Nepal Food Corporation of Ramechhap brings rice into the headquarters in this way. A porter receives 30 $\mathrm{kgs}$. of rice for carrying $100 \mathrm{kgs}$. from Sindhuli, the headquarters of the adjoining district, to Ramechhap. In this case as in most instances, a porter carrying an average size load of $60 \mathrm{kgs}$. takes about three days to reach Ramechhap from Sindhuli.

\section{Objectives of the Study}

This article is an attempt to document the socioeconomic profile of the paid porters belonging to one of the weaker sections of Nepali society. Porterage, particularly in the hills of Nepal, is overwhelmingly an activity contributing to the earnings necessary for its existence of the weaker sections of the population. Seddon et al. $(1981: 90)$ have also opined that porterage as an only or dominant source of income is almost unkmown.

The daily behavior of the porters is organized to balance production, income and consumption of resources through the division of household labor, both within and without the home. These balances are referred to as survival strategies. They also encompass a range of responsibilities among family members. These arrangements are essentially normatively or socially defined, and they are modified according to changes in the surroundings or other circumstances, be they economic, social, or ecological.

\section{Methodology Employed}

Ramechhap and Sindhuli Districts, of the central mid-hills of Nepal, were purposely chosen as the location for this study. One Panchayat in each of the districts was chosen for survey. The survey was carried out during the month of January, 1988.

Based on the nature of the problem, the headquarters of the districts, Ramechhap and Siddheswor (Sindhuli) village Panchayats, were selected.

The methodologies include both quantitative surveys and indepth micro-level observation. 


\section{Study Sample}

Due to the lack of a data base, the researcher applied a judgmental sampling technique preceded by a prior consultation with a few key informants from both of the Panchayats. It was decided to interview ten percent of the total estimated porters from both Panchayats. Thus, in Ramechhap, 35 porters were interviewed. Likewise, 33 porters were interviewed in Siddheswor (Sindhuli). Of the total respondents interviewed, 20 percent in Ramechhap and 25 percent in Sindhuli were females. The names of the respondents were randomly selected.

It is expected that the sample size was sufficiently large to be statistically representative and to indicate the trends and patterns of the porters and their socioeconomic environment. Despite a fairly large sample size, every effort was made to capture indepth qualitative information on the living condition of the porters and the socioeconomic environment in which they operate.

A simple problem-oriented questionnaire was used to gather primary information. In addition, observation and group interviews were used to solicit the relevant information.

\section{Analysis and Discussion}

Family Size

The families of the majority of the porters consisted of 5 to 8 members. In Ramechhap and Sindhuli this size range represented 51.43 and 57.57 percent respectively.

The average family sizes in the Ramechhap and Sindhuli Panchayats were 7.28 and 6.69 respectively (see Table 1 in Appendix 1). These averages are larger than that characterizing the districts as a whole. The reason for the larger family sizes of the selected Panchayats might be in the nature of the respondents. Poorly educated, they lack knowledge and access to family planning. It is also predictable that they may feel that the number of children they have makes no difference in their lives.

\section{Farm Land}

In Ramechhaj, the majority of the porters (37 percent) held an average of 0.50 to 1.00 ha. of land. All of them held marginal bari lands (unirrigated upland). This bari was fragmented into many parts with an average size of 0.74 ha.
In Sindhuli, more than half of the sample respondents $(52$ percent) held $0.25 \mathrm{ha}$. or less of farmland. The average size was 0.35 ha. (Table 2).

This small size of the landholdings has been a crucial factor forcing the people to seek other sources of income.

\section{Ethnic Composition}

In Ramechhap, 25.71 percent of the people were Brahmin or Kshatriya. Tamangs represented the next largest group (21.37 percent). The majority of the Tamangs work as porters. In Siddheswor (Sindhuli), most of the residents were Tamang (40 percent), making the second greatest contribution to the total labor (Table 3).

In Ramechhap, the Tibeto-Burman Tamang, Hayu and Kasai groups represented the majority of the porters, with distributions of 29,23 and 22.8 percent respectively. Among Tamangs and Kami, men and women were equally engaged in porterage, while among the Hayu, the male to female ratio was $60: 40$.

In Siddheswor (Sindhuli), the majority of people ( 30.3 percent) were of the Sarki untouchable or occupational leather worker caste. The male to female ratio among the Sarkis was $1: 1$. The Tamang were next in number ( 24.2 percent), again with equal numbers of men and women engaged in porterage (Table 4).

From these findings, it is clearly evident that both males and females engage in porterage. The significant difference is along caste lines. The upper caste Brahmins and Kshatriyas are negligibly involved in porterage. Our fieldwork indicates that alternative sources of income and higher socioeconomíc status were significant factors. To some extent these groups were more literate and educated than the other castes. This placed them in a position to obtain other jobs in the village and elsewhere to contribute to household income. On the other hand, the majority of the lower caste and Tibeto-Burman groups engaged in porterage from their early teenage years in order to survive.

\section{Food Deficit Situation at the Household Level}

In both of the Panchayats surveyed, all the porters interviewed experienced food deficits from March until August, especially June through August. This indicates that the only immediate option for these households is porterage. The people's greatest need arises during the monsoon season (Tables 5 and 6). The fieldwork showed that Ramechhap is food deficit, and that much of Sindhuli suffers floods. According to the porters, they are relatively idle from 
December to March. During these months there is even little of their marginal agricultural work.

Detailed investigation on food availability and sufficiency for different groups within Nepali society has rarely been carried out. This is unfortunate, because malnutrition affects all castes and ethnic groups in the pre-monsoon months from March and May. The condition of the people in this study was no exception. The principle factor is inadequate landholding, leading to insufficient staple food crop production and an inability to earn cash to buy extra food.

\section{Sectorwise Employment Structure and Wage Rates}

In Ramechhap, the majority of respondents (42.85 percent) experienced only three months of employment in the agricultural sector. However, 25.71 percent obtained 6 months employment in the nonagricultural sector. This employment situation was similar to the case of Sindhuli (Table 7).

In both Panchayats, men and women received different wage rates. In Ramechhap, the government daily wage rates were Rs. 24.00 and Rs 20.00 for men and women, respectively. The daily wage rates were lower in Sindhuli, where men and women received Rs 20.00 and Rs 16.00 respectively. The workday is generally 8 hours long. However, the skilled laborers and the group leaders receive slightly more than the others. The rates for skilled labor depend on the nature of the work involved. ${ }^{2}$

In the private sector and in the household, discrimination between men's and women's wages exists. In Ramechhap, the daily wage rate for men was Rs 20.00 per day with three manas

(approximately $1.5 \mathrm{kgs}$.) of available food grains. Likewise, women received Rs 15.00 per day and the same quantity of food grains. In Sindhuli, the differential of wage rates for female and male labors at the household level resembled that of Ramechhap. The researchers observed that in both panchayats, the food grains or snacks received as part of the wages contain millet and maize. These wage rates were general, but varied according to the type and nature of the work done. in most cases at the household level, the working day was longer than 8 houss.

Field observations support that even in the agricultural sector. the majority of the respondents had to work as wage earners on fields owned by others. In the nonagricultural sector, porterage represented the major source of income. This was especially true for Ramechhap. Ramechhap dwellers had to transport their consumer goods by foot from the headquarters at Sindhuli. Because of the nature of employment in the non-agricultural sector, this sector is uncertain. Additionally, the carriers remained idle during the monsoon months.
In Ramechhap proper, unlike Sindhuli, the majority of the residents are engaged in porterage. They receive only Rs 6 to 7 for each dharni ( $2.5 \mathrm{kgs})$ of goods carried from Sindhuli to Ramiechhap.

\section{Consumption Pattern of the Porters at the Household Level}

Since food is the primary human need, this study was also directed to observe and document the consumption pattern of the porters. It was noted that maize is the staple diet of the respondents, occupying the top position in the regular diet of 98 percent and 70 percent of the porters in Ramechhap and Sindhuli Panchayats. respectively. Other more frequently consumed grains include pulses (horse gram and masyang) and millets (finger millet and buck wheat) The least frequently consumed grain is wheat (Table 8). However, it was difficult to observe whether the porters had the opportunity to consume rice.

The reasons given by the respondents for these consumption patterns were:

1. Only maize is grown on their marginal bari lands, since these are only suitable for maize.

2. Maize has been in their regular diet since their early childhood.

3. Because of their economic limitation they have to survive with maize.

4. Maize serves a duel purpose: human food and livestock feed. Maize is mainly consumed in the form of grit. During the process of grit making (milling ${ }^{3}$ ) the flour comes out as a byproduct which is fed to livestock. Livestock raising is and integral part of the household farming economy. Maize grain can be used for making local beverages such as rakshi and Jand Rakshi. Jand making and drinking is quite common among the porters in the hills of Nepal.

\section{Concluding Remarks}

Although evidence is sparse, it can be safely stated that paid porterage has existed for a quite a long time in Nepal simply to meet the basic needs of society in the arduous hill communities of Nepal. However, an inadequate data base prohibits the exact measurement and analysis of these activities. These activities largely lie between the boundaries of the usual rural versus semi-urban or urban culture, and between agriculfural and nonagricultural categories. These classifications inevitably involve a degree of arbitrariness since they 
impose a single dividing line on what actually contains a continuous spectrum of situations in the contemporary hills of Nepal.

Population pressure, subsistence farming, low productivity, and lack of transportation and communication facilities are among the reasons forcing the bulk of the hill population into this strenuous form of labor for their living. This section of the hill society supplements its household expenditure with porterage, which is the only viable alternative source of income.

However, a fuller assessment of the significance of this nonfarm income for the rural poor must await the results of research into rural wage and market structures. This will be of particular importance to the landless or near landless farm households-i.e., the poorest of the rural poor in the hills of Nepal. What is important here is that any reduction in the dependency on porterage and the consequent increase in rural income among these vulnerable low-income groups will depend heavily upon the growth of demand for rural labor outside agriculture. For instance, through the provision of social and economic infrastructure to the hills, a substantial impact on the development of local nonfarm activities can be made.

Small manufacturers, services and crop-processing enterprises, for example, are among the primary beneficiaries of rural

electrification. Roads in the hills enable new nonfarm activities. Hill roads also give these groups greater access to education, health, and many other social amenities, and thus they are an important factor to be considered for investment programs.

However, Seddon et al. (1981:104) concluded that porterage is merely a symptom of underdevelopment. The author of this article visualizes that in the present hill context of Nepal, paid porterage serves hill society. It provides basic needs on the one hand. and it is a major source of livelihood for a bulk of this vulnerable section on the other. Nonetheless, it is rational to infer that the impact of modernization in the agricultural sector, as well as in other developmental activities, is not as unilinear as might be expected. Hence, to minimize the miserable conditions of the people, the overall development is most acute in the hills of Nepal. In spite of many sincere attempts, the policies, programs and projects have not contributed adequately to the poor, and their situation has shown little or no improvement.

In this article, an attempt has been made to provide a small data base for porterage. Porters are wage earners about whom little is known, but they are an integral part of the hill communities of Nepal. This study provides basic data to researchers and policy makers.

\section{Appendix: Tables}

Table 1. Family size of porters in Ramechhap and Siddheswor (Sindhuli) Panchayats (in percent)

\begin{tabular}{|lcc|}
\hline \multicolumn{1}{|c|}{ Family Size } & Ramechhap & Sindhuli \\
\hline Less than 5 persons & 22.85 & 18.18 \\
5 to 8 persons & 51.43 & 57.57 \\
More than 8 & 25.71 & 24.25 \\
\hline Average Family Size & 7.28 & 6.69 \\
\hline
\end{tabular}

Table 2. Size of lands held by the porters (in percent)

\begin{tabular}{|ccc|}
\hline Farm Size (ha.) & Ramechhap & Sindhuli \\
\hline $0-0.25$ & 18 & 52 \\
$0.25-0.50$ & 25 & 28 \\
$0.50-1.00$ & 37 & 17 \\
Larger than 1.00 & 20 & 03 \\
\hline Average Size & 0.74 & $\mathbf{0 . 3 5}$ \\
\hline
\end{tabular}

Note: Less than 5 percent of the respondents owned khet (wet lowland) in both Panchayats.

Table 3: Ethnic composition of the Ramechhap and Siddheswor (Sindhuli) Village Panchayats (the study area)

\begin{tabular}{|lcc|}
\hline Composition & Ramechhap & Sindhuli ${ }^{2}$ \\
\hline Brahmin/Kshatriya & 25.71 & 25.0 \\
Tamang & 21.37 & 40.0 \\
Hayu & 11.08 & - \\
Newar & 14.05 & 15.0 \\
Kasai & 11.79 & - \\
Magar & 11.00 & 5.0 \\
Sarki/Kami/Damai & 5.00 & 10.0 \\
Others & - & 5.0 \\
\hline
\end{tabular}

Others 5.0

2Pradhan Pancha, Siddheswor Village Panchayat. 
Table 4: Ethnic composition of the porters and the ratios of men to women engaged in paid porterage

\begin{tabular}{|l|rrr|rrr|}
\hline Composition & \multicolumn{3}{|c|}{ Ramechhap } & \multicolumn{3}{c|}{ Sindhuli ${ }^{2}$} \\
& \multicolumn{1}{c|}{$\%$} & Men & Women & \multicolumn{3}{c|}{ Men Women } \\
\hline Tamang & 29.0 & 50 & 50 & 24.2 & 50 & 50 \\
Magar & 14.3 & 70 & 30 & 3.1 & 60 & 40 \\
Kasai & 22.8 & 50 & 50 & - & - & - \\
Hayu & 23.0 & 60 & 40 & 3.0 & - & - \\
Kami & 5.2 & 40 & 60 & 6.1 & 40 & 60 \\
Sarki & 2.8 & 50 & 50 & 30.3 & 50 & 50 \\
Newar & 2.9 & 80 & 20 & 6.0 & 80 & 20 \\
Kshatriya & - & - & - & 12.0 & 75 & 25 \\
Gharti & - & - & - & 12.1 & 50 & 50 \\
Brahmin & - & - & - & 3.2 & 95 & 5 \\
\hline
\end{tabular}

Sources: 1 District Panchayat and Village Panchayat, Ramechhap.

${ }^{2}$ Pradhan Pancha, Siddheswor Village Panchayat.

Table 5: Number of food deficit months among the porters at the household level (by percentage of households)

\begin{tabular}{|ccc|}
\hline Deficit Months & Ramechhap & Sindhuli \\
\hline 3 & 5.71 & 0.00 \\
4 & 5.73 & 15.15 \\
5 & 25.71 & 24.24 \\
6 & 20.00 & 18.18 \\
7 & 20.00 & 12.12 \\
8 and above & 22.85 & 30.31 \\
\hline
\end{tabular}

Table 6. Acute food grain deficit months faced by the porters by numbers of households (in numbers of households)

\begin{tabular}{|ccc|}
\hline $\begin{array}{l}\text { Months } \\
\text { (n=35) }\end{array}$ & $\begin{array}{c}\text { Ramechhap } \\
(\mathrm{n}=33)\end{array}$ & Sindhuli \\
\hline April/May & 30 & 32 \\
May/June & 34 & 32 \\
June/July & 33 & 31 \\
July/Aug & 29 & 9 \\
Aug/Sept & 8 & 5 \\
Sept/Oct & 4 & 6 \\
Oct/Nov & 3 & 6 \\
Dec/Jan & 5 & 8 \\
Jan/Feb & 22 & 20 \\
Feb/Mar & 27 & 26 \\
Mar/Apr & 33 & 32 \\
\hline
\end{tabular}

Table 7. Employment structure of porters by sector in terms of number of months employed (in percent)

\begin{tabular}{|c|rc|cc|}
\hline $\begin{array}{c}\text { Number } \\
\text { of } \\
\text { Months }\end{array}$ & $\begin{array}{c}\text { Ramechhap } \\
\text { Agri. } \\
\text { Sector }\end{array}$ & $\begin{array}{c}\text { Non-Agri. } \\
\text { Sector }\end{array}$ & $\begin{array}{c}\text { Agri. } \\
\text { Sector }\end{array}$ & $\begin{array}{c}\text { Sindhull } \\
\text { Non-Agri. } \\
\text { Sector }\end{array}$ \\
\hline 1 & 8.57 & - & 33.33 & 3.03 \\
2 & 17.14 & 5.17 & 18.18 & 3.03 \\
3 & 42.85 & 8.57 & 36.36 & 9.09 \\
4 & 17.14 & 14.28 & 12.13 & 3.03 \\
5 & 8.57 & 8.57 & - & 24.25 \\
6 & 5.73 & 25.71 & - & 15.15 \\
7 & - & 5.73 & - & 9.03 \\
8 & - & 17.14 & - & 9.09 \\
9 & - & 14.29 & - & 24.24 \\
\hline
\end{tabular}

Table 8: Food consumption of the porters at the household level

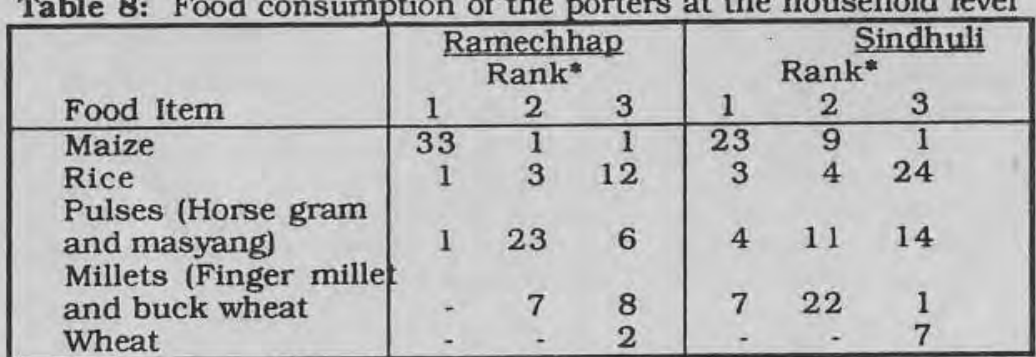

$\begin{array}{llll}\text { Wheat } & - & 2 & -\end{array}$ Frequent

\section{Notes}

1This article arose out of research carried out by the author on the "World Food Program" assigned by UNDP/FAO, in January-February. 1988

2The information on the wage rates and working day is among government employees is based on discussions at the District and Village Panchayats of the study area.

${ }^{3} \mathrm{An}$ indigenous stone grinder called a janto is used for milling.

\section{References}

HMG/N, National Planning Commission

1978 A Survey of Employment, Income Distribution, and Consumption Patterns in Nepal. Kathmandu.

HMG/N, CBS

1987 Population Monograph of Nepal. Kathmandu. 
1984 Population Census-1981. Kathmandu.

Pant, Y. P. and S. C. Jain

1980 Rural Problems and Development in Nepal. New Delhi: Development Publishers

Seddon, David, Piers Blaikie, and John Cameron

1981 Peasants and Workers in Nepal. New Delhi: Vikas Publishing House, Pvt. Ltd.
EMPLOYMENT, WORKING CONDITIONS AND MODE OF LIVING:

\section{THE CASE OF THE NEPALI WATCHMEN IN BOMBAY I}

Phanindreshwar Paudel

\section{Introduction and Methodology}

Nepali laborers in Bombay are engaged in various economic activities. They are employed in many different industries and occupations. Among these, the job of watchman.employs quite a sizable number of Nepali laborers in Bombay. ${ }^{2}$ By and large, the Nepali watchmen are employed to guard blocks of offices, banks, factories, commercial complexes, residential colonies, private buildings, and the like.

This paper attempts to highlight the employment, working and living conditions of the Nepali watchmen in the city of Bombay, with an emphasis on the relation of these issues to a few selected background factors. It was hypothesized that the employment, working and living conditions of these people improve in relation to their personal and employment backgrounds. The hypotheses related to these issues have been tested against primary quantitative survey data collected in the field in 1988 .

A quota sample design and snowball sampling procedure were used to draw a sample of 58 watchmen from three sectors of employment, namely, public institutes, industrial and commercial enterprises, and housing cooperative societies. Data were collected by means of interview and observation techniques. The data were analyzed with the help of univariate and bivariate tables prepared on machines. While univariate tables were interpreted on the basis of percentage distribution, the trends in the bivariate tables were ascertained by using the chi-square $\left(\mathrm{X}^{2}\right)$ test. The hypotheses were accepted or rejected by considering the value of chi-square $\left(\mathrm{X}^{2}\right)$ at a 0.05 level of significance. However, the non-random sample design and small sample size have been admitted as the major limitations of the study. 